\title{
Globalization Of Entrepreneurship: Policy Considerations For SME Development In Indonesia
}

\author{
Balbir B. Bhasin, Sacred Heart University, USA
}

Sivakumar Venkataramany, Ashland University, USA

\begin{abstract}
SMEs are of overwhelming importance to the young and growing economies of most Southeast Asian nations, including Indonesia. The country is a vast polyglot archipelago, struggling with poverty and unemployment, poor and inadequate infrastructure, rampant corruption, insufficient capital, and unequal distribution of resources. It has recently experienced fundamental changes in political governance, regional empowerment, and economic structures as a result of the Asian Financial Crisis, coupled with widespread social unrest which resulted in the ouster of the authoritarian regime of President Suharto. This paper evaluates the existing private sector development policy in Indonesia, which has been found to be both ambivalent and inconsistent. The Guided Democracy and Guided Economy policies of the post-independence era were socialist in nature. The subsequent New Order regime provided preferred treatment to selected segments of society. In order to succeed in promoting SME development to advance the welfare of the economically weak groups, the newly launched programs need to be fine-tuned to allow for the establishment of a favorable and non-discriminative investment climate. There is much that Indonesia can learn from the experience of India and Singapore in implementing meaningful policy that can effectively promote SME development, especially in the production, distribution and service sectors in a global context. Policies have to be market-oriented, demand-driven and not dominated by government agencies which, in the past, have failed to provide services relevant to the actual needs of SMEs.
\end{abstract}

Keywords: Globalization, Entrepreneurship, Small \& Medium-sized Enterprises (SMEs)

\section{INTRODUCTION}<smiles>[C]1C=CCCC1</smiles>

mall and medium sized enterprises (SMEs) are a key engine of growth for Indonesia's economy as they are for most developing countries in South and Southeast Asia. Indonesia has been through a very rough patch in its development since independence in 1949. It is the fourth largest country in the world in terms of population and the world's third largest democracy, the world's largest archipelagic state, and home to the world's largest Muslim population. It is facing numerous challenges, including alleviating poverty, controlling overpopulation, improving education, fighting terrorism, consolidating democracy after decades of authoritarian rule, stemming endemic corruption, coping with natural disasters, environmental damage, and implementing economic and social reform. Due to political upheavals, the country's policies concerning development of SMEs has been haphazard, to say the least. This paper traces the evolution of Indonesian policy toward SMEs over the three generations of development of the economy, evaluates the effectiveness of current policy, and makes recommendations that can contribute to achieving a more cohesive framework and benefit by learning from neighboring countries for optimum results. SMEs in Indonesia are defined as enterprises with less than 100 employees. 


\section{BACKGROUND: SME POLICY EVOLUTION IN INDONESIA}

Indonesian SMEs account for more that $90 \%$ of all firms outside the agricultural sector. Hence, they are the biggest source of employment and provide the major source of income for more than $90 \%$ of the country's workforce (Tambunan, 2008). The majority of these SMEs are typically very small units and are spread out throughout the rural area, which for Indonesia is vast indeed. The country consists of almost 14,000 islands as an archipelago in tropical Southeast Asia north of Australia and south of Peninsula Malaysia. The country's land area is three times the size of Texas and covers a span of over 5,000 kilometers from east to west. It has a population exceeding 240 million (estimated July 2009) with a per capita GDP of only $\$ 3,900$ and a labor force of around 112 million. Main agricultural products are rice, cassava (tapioca), peanuts, rubber, cocoa, coffee, palm oil, copra; poultry, beef, pork, and eggs; and industries include petroleum and natural gas, textiles, apparel, footwear, mining, cement, chemical fertilizers, plywood, rubber, food, and tourism. The country has relied mainly on agricultural and mineral resources, including palm oil, rubber, coffee, copra and some seafood for foreign currency. In the last two years, Indonesia has had a growth rate of around $6 \%$ but direly needs to increase non-petroleum exports. The country has been through much upheavel after gaining independence from colonial masters - the Netherlands - after the War of Independence in 1949. Changes in the political climate directly affected SME policy in Indonesia and can be summarized as three generations of evolution (Thee, 2006).

\section{THE EARLY INDEPENDENCE PERIOD 1950-1965}

The bitter experience of exploitation by the Dutch masters caused the policy makers to be quite averse to capitalism and sought socialism to be the way to develop their economy. President Sukarno chose and promulgated economic nationalism, and the first quarter of a century of post independence was devoted mainly to offset the imbalance of economic power held mainly by Dutch and Chinese businesses in favor of the indigenous Indonesians who had been left behind rather severely. This Guided Democracy and Guided Economy policy promoted State Owned Enterprises (SOEs), as opposed to private enterprise, as the vehicle for economic development. Nationalism became the order of the day and banks, public utilities, railways, and many other Dutch and Chinese-held private enterprises were turned over to SOEs. Attempts to foster an ethnic Indonesian business cadre were not very successful due to the lack of entrepreneurial capability, which was mainly Chinese-held, including SMEs in the rural areas. The most conspicuous policy implemented to achieve Indonesian entrepreneurial dominance was through restricted granting of Import Licenses. The main reason this policy did not succeed was that there were few bona fide indigenous enterprises - most were structured around the "Ali-Baba" method where the locals were front men and the Chinese businessmen were actually running the operations. The failure of this policy resulted in major antiChinese backlash and the affirmative action policy was discontinued by decree. In spite of governmental efforts to socialize the economy through SOEs, entrepreneurship and SMEs continued to be held in Chinese hands. Only food crop and cash crop smallholder agriculture remained privately owned.

\section{THE NEW ORDER PERIOD 1965-1998}

With the transfer of power from Sukarno to Suharto after the military coup, a new economic direction resulted in 1966. This New Order was an about turn of policy with regard to business-government relations. The existing policy of state dominance in the economy was abandoned. Controls on private enterprise were removed and local and foreign direct investment was encouraged. Monopolies of SOEs were abolished and they were no longer required to sell their products at below market prices. A new Foreign Investment law was enacted in 1967 in which attractive incentives, generous tax concessions, and guarantees against arbitrary nationalization were provided. A major development was that unlike the past policy - no questions were asked about the legitimacy and origin of the funds to be invested in Indonesia. This meant that no back taxes were to be imposed and investments and enterprises grew rapidly. The net result was that economic development in a real sense had started.

However, "instead of fostering a healthy development of the private sector, through patronage, the New Order nurtured the growth of a dependent capitalist class of client businessmen" (Thee, 2006). The culture of cronyism and nepotism based on preferential treatment of the Presidential family and friends, Chinese and other selected businessmen, based on the 'reciprocity principle', became prevalent. The net result was the creation of large market-oriented enterprises which were not internationally competitive. Development of SMEs was given 
priority through several promotion programs, but remained largely ineffective. It was understood that this was to serve as a counterweight to the stronghold of Chinese-held ventures. Interests of political elites prevented the growth of SMEs.

\section{THE REFORMATION PERIOD}

The end of the Suharto era in 1998 came about in the midst of the great Asian financial economic crisis which affected South Korea, Thailand and Malaysia as well. Indonesia suffered immensely with the contraction of the economy by $14 \%$ and the severe devaluation of its currency, the Rupiah. There was substantial capital flight to Singapore and elsewhere, especially by ethnic Chinese business people. With the introduction of democracy and regional empowerment through the amended constitution, a new day had dawned for SMEs in Indonesia. SME development was being accorded much greater attention by the successive new governments of the post-1998 era. A major restructuring had taken place. Many unviable SMEs had to go out of business, but the biggest change was the recognition that global markets were open to those enterprises that were efficient, creative and competitive.

\section{LITERATURE REVIEW: SME POLICY AND PERFORMANCE IN INDONESIA}

The task for formulation of SME policy in Indonesia rests with the Ministry of Cooperatives and Small and Medium Enterprises (MSME), which has the following stated mission:

To fulfill a real contribution to national development through the formulation of national policy, coordination of planning, implementation and regulation for the empowerment of Cooperatives and SMEs, and increasing the synergy and active role of producers and the business world in order to enhance productivity, competitiveness and independence of Cooperatives and SMEs systematically, continuously in a nationally integrated manner (MSME, 2009).

Indonesian SMEs include a very large number of micro enterprises (called MIEs) which are essentially self-employed individuals (or core family members) and are spread out throughout the rural hinterland. The majority of these eke out subsistence living. These, and many SMEs too, are poorly run with minimal capital, low in productivity and technology and with poor products. Indrati and Langenberg (2004) sought to confirm why some SMEs in Indonesia declined or remained stagnant while others were successful and growing. They also ventured to ascertain: "What factors affect business success among SMEs in Indonesia". Based on a survey of 100 SMEs, the study found that marketing, technology and capital access affected business success positively in a significant way, while legality did in a negative way.

In a case study covering internal and external factors affecting success of SMEs in Indonesia, Susanto (2005) found that entrepreneur development needed to be managed in a centralized, integrated and comprehensive manner in one agency. The case for Indonesia was that it was too dependent on external factors that included lack of funding, high interest rates, high taxation, and burdensome government requirements in seeking support. Cole (2007) examined the cultural factors affecting entrepreneurial development. Using Hofstede's cultural dimensions as a starting point, he examined the relationship between cultural dimensions and entrepreneurship. The analysis reinforced previous work that had suggested that high power distance, uncertainty avoidance and collectivism all hinder entrepreneurship. While the case study confirmed that a lack of knowledge and structural support could be constraining factors for entrepreneurs, the influence of the government to hinder entrepreneurship was far greater. The study also identified that a lack of understanding, confidence and education acted as barriers to the entrepreneurial potential of the community.

Prihatin Dwi Riyanti (2004) conducted an exploratory study to identify factors affecting the success of entrepreneurs at the SME level in Indonesia. Her study indicated that certain variables could be used to accelerate the development of SMEs. They were:

1. Age and experience of the entrepreneur allowed individuals to exploit sources for success in the business world.

2. Personality traits contributed to innovative behavior, which led to business success. 
3. Involvement in managing a business could lead to the emergence of new entrepreneurs.

In 2000, the USAID funded "Partnership for Economic Growth Project" observed that (Timberg, 2000):

1. The "Old Paradigm" of SME development in Indonesia used a lot of money to little effect. The politicians and bureaucrats tended to focus on subsidies that assisted uncompetitive and inefficient enterprises. The net result was that banks that served SMEs were in ruins, technical assistance organizations un-patronized and many assisted enterprises closed.

2. This resulted in the emergence of the "New Paradigm" where finance and services were provided at market rates or with meaningful broad-based subsidy. The subsidy provided start-up costs, creating self-sustaining units rather than income subsidies to the clients.

However, most players in the Indonesian enterprise promotion system had their own systems that they wished to advance. All the participants are in continuous competition for the subsidy budgets. The newest players were the provincial governments that had their own developmental institutions (Timberg, 2000). Although the Indonesian economy grew rapidly in the three decades before the Asian Crisis in 1998, the policies for promotion of SMEs did not work well, mainly because of "inadequate design of programs and insufficient implementation of capabilities of the government" (Hayashi, 2004).

In 2002, an Asian Development bank study on SME trade and export promotion in Indonesia found that:

1. Most governmental promotion efforts have neither resulted in a sustainable long-term increase in SME exports, nor contributed significantly to export diversification.

2. Export promotion focused primarily on short-term activities geared at individual companies, while neglecting networking among firms, joint marketing efforts, and the potential of foreign investment to develop export-oriented SME through subcontracting linkage.

The ADB observed in 2006 that it was unsure if the Indonesian government would pursue market-oriented, demand-driven policies to develop viable and efficient SMEs or would still continue "policies guided by populist or 'welfare considerations', particularly by providing large amounts of subsidized credit" (Thee, 2006). The major concern was that many government officials and politicians having this tendency would not contribute to viable SME development. Tambunan (2007) found that sufficient data were not available in research to ascertain the effectiveness of government-supported SME development programs. The main problems were program coverage, lack of cooperation among government institutions, as well as non-government and executing agencies, and often such programs were not supported by state economic policies.

Tambunan (2008) also studied the effects of SME development policy in Indonesia and found that government development expenditure in promoting SME growth in Indonesia had positive results, both directly and indirectly. In terms of output in 2006, SMEs in Indonesia performed relatively well. Small Enterprises (SEs) and Medium Enterprises (MEs) grew at 3.96\% and $4.5 \%$ in 2001 to $5.38 \%$ and $5.44 \%$ in 2006. Less experienced growth rates of $3.04 \%$ and $5.60 \%$, respectively, during the same period are illustrated in Table 1.

Table 1: Total unit of enterprises by size category 2001-6 ('000 units)

\begin{tabular}{|l|c|c|c|c|c|}
\hline Size Category & $\mathbf{2 0 0 1}$ & $\mathbf{2 0 0 3}$ & $\mathbf{2 0 0 4}$ & $\mathbf{2 0 0 5}$ & $\mathbf{2 0 0 6}$ \\
\hline SEs & 39,883 & 43,327 & 44,684 & 47,006 & 48,822 \\
\hline MEs & 80.97 & 87.4 & 93.04 & 95.9 & 106.7 \\
\hline LEs & 5.9 & 6.5 & 6.7 & 6.8 & 7.2 \\
\hline Total & 39,969 & 42,466 & 44,784 & 47,109 & 48,939 \\
\hline
\end{tabular}

Source: Indonesian National Agency for Statistics (BPS); adapted from Tambunan, 2008

In 2004, APEC received a submission from Indonesia on the perspective of regulation covering SME development. The government, through the Agency for Technology Development and Implementation (BPPT), had developed a policy for the development of "technopreneurs". The following challenges were identified: 
1. Indonesia lacked professional institutions for educating and training entrepreneurs.

2. There were social and cultural impediments to entrepreneurial development. People preferred to work in government after completing their tertiary education.

3. Indonesia lacked a cadre of experienced entrepreneurs who could teach, train and educate common people to become entrepreneurs.

4. Indonesia lacked good programs for entrepreneurship development.

In 2008, APEC received a report that the total number of SMEs in Indonesia were 48.9 million and made a contribution of $53.28 \%$ to the GDP and $96.6 \%$ to employment. The majority of them were engaged in primary sectors (60\% agriculture) and cottage industries. But the average growth of SMEs in five years (from 2001-2006) averaged only $1 \%$. The major challenges and weaknesses were:

1. Lack of access to productive resources

2. Low quality of human resources

3. Lack of economies of scale for service providing institutions

4. Majority of SMEs were MIEs with low productivity

5. High administration and transaction costs

6. Structural economic gap - hollow in the middle

7. Globalization of economy and trade liberalization - greater competition

At the same meeting, APEC (2008) also received a report that while globalization of SMEs was rapidly taking place, only a small percentage $(0.05 \%)$ of Indonesian exporters was exporting directly. Most were going through third party trading houses. This was due to the following problems:

1. Limited financial access to foreign markets

2. Many SME products did not meet export standards

3. Inability to understand information relating to world markets

The UNCTAD-sponsored Global Program met in 2004 to evaluate Indonesia's SMEs preparedness to meet challenges of globalization and concluded that "for too long the government has overlooked SMEs and paid too much attention to LEs. The economic structure is biased against SMEs and needs to be overhauled" (UNCTAD, 2004). Policies need to be created that develop a domestic entrepreneurial class. Currently policies only led to a high cost economy and loss of competitiveness of SMEs.

1. The administration process was slow and cumbersome for entrepreneurs, procedures were cumbersome, and too many permits were required.

2. The rampant bribery led to higher costs.

3. The tax structure was an impediment to creation of SMEs.

4. There was weak protection of property rights.

5. There were problems in getting visas in foreign markets, which prevented liaison with foreign clients.

6. Too many SMEs needed support and resources were limited; not all SMEs had potential for growth.

7. Support should be given to SMEs that were innovating and outward-oriented.

8. Financing was a serious problem due to un-bankability, lack of collateral, poor managerial skills, and too small or too risky ventures.

9. There was a lack of technical expertise and low access to technology.

10. Policies were needed to encourage subcontracting with LEs at home and abroad.

11. Even though the Rupiah is low in value, Indonesia continues to be uncompetitive due to inadequate infrastructure.

12. There is a lack of coordination and cooperation among departments responsible for SME development. There are too many institutions, there is a lack of a coordinated and integrated approach, and there is no Master Plan for developing SMEs.

In the World Development Report 2000-2002, Weaver and Wallace (2000) submitted that Indonesia should develop new policies that focus on using strategic alliances that have shown to contribute to increasing growth, 
facilitating technology transfer, offering alternative financing resources, providing access to markets, encouraging licensing arrangements, increasing profits, and enhancing a firm's ability to compete.

\section{DISCUSSION: POLICY CONSIDERATIONS FOR INDONESIA}

As a prelude to discussing policy considerations, the value of the contribution that the SME sector makes to the national economy must be recognized more substantially. Most East Asian governments do recognize the importance of SME development as essential and necessary for the overall health of each country's economy. The SME sector accounts for upward of $90 \%$ of all firms outside the agricultural sector and the biggest source of employment, providing livelihood for three quarters of the region's population. This is also the case for Indonesia:

The contribution of SMEs in 2003 was $56.7 \%$ of the total national GDP. This was broken down into $41.1 \%$ and $15.6 \%$ contribution by micro and small enterprises, and medium enterprises, respectively. SMEs employ more than 79.0 million people, or $99.5 \%$ of total employed, including 70.3 million people in micro and small enterprises, and 8.7 million people in medium enterprises. Based on that data, it can be affirmed that SME's have a big role in providing employment. (MSME, 2009)

In spite of the importance of SMEs to the national economy, the country still lacks an established, well crafted and effectively managed policy for the development of a strong base of corporate and entrepreneurial leaders. It becomes imperative that first a comprehensive strategy, followed by a detailed plan, and then its implementation becomes a priority for the country. Discussed below are some policy considerations. Table 2 illustrates the level of economic activity of the country as a whole for 2007. Another absolutely important consideration is the need to develop SMEs that are capable of competing in the global marketplace. Exports not only allow for the earning of valuable foreign currency, but open new and dynamic markets that provide higher returns. This is absolutely essential to job creation, which is clearly a priority for Indonesia. Table 3 shows the current international trade position.

With access to larger markets, SMEs can benefit from economies of scale, generate greater revenues, and acquire new skills, new technology and new marketing techniques. This will allow for greater productivity and efficiency. Exporting will also speed up the multiplier effect and help spread the skills learned by many small producers and have a positive effect on the entire economy. The key to the future success of SMEs will be capacity building, which will enable them to take advantage of opportunities arising from globalization. Harvie (2004) suggests that for SMEs in Asia to fully participate in the process of globalization, they must develop capacities that will enable them to compete in global markets. As early as 1997 at the APEC meeting in Ottawa, these were highlighted as:

1. Access to markets. In the light of rapid trade liberalization, SMEs need to take advantage of opportunities arising out of the more open regional trade system as in ASEAN (Association of South East Asian Nations). As a result of cuts in tariffs by APEC from 12\% in 1995 to $8 \%$ in 2000, exports grew by $4.7 \%$ per annum during 1995-2000.

2. Access to technology. The fast development of e-commerce is opening new doors and markets for many small firms. E-commerce presents small businesses with a chance to compensate for traditional weaknesses when competing with larger firms. Communications, flow of information, and linking buyers and sellers are some examples. The new trend toward knowledge-based economies requires that small businesses need to incorporate technology into all levels of activity.

3. Access to financing. Availability of financing from maximum sources needs to be promoted more effectively in helping start-ups, as well as expanding SMEs. Procedures for granting of loans at all levels needs to be simplified and financial institutions need to be more proactive in their efforts, especially with regard to micro financing.

4. Access to information. Government agencies responsible for developing SMEs need to provide access to timely and accurate information in the areas of market opportunities, availability of financial resources, new development in technology, etc. for these firms to grow and compete in the global market. 
The new developments in the global context need to be recognized and taken fully into account in policy formulation. Wattanapruttipaisan (2002) notes that "there are more opportunities for inter-firm linkages for enhanced collective efficiency, technological innovation capabilities... in particular, the complex proliferation of international production and cross-border supply chains has widened and deepened the potential and avenues for SME involvement."

Table 2: Indicators of Productivity: Indonesia

\begin{tabular}{|l|c|}
\hline GDP (Rupiah, billions) & 3957404 \\
\hline Structure of output (\% of GDP) & 13.8 \\
\hline Agriculture & 46.7 \\
\hline Industry & 39.4 \\
\hline Services & \\
\hline Growth of output (annual change \%) & 6.3 \\
\hline GDP & 3.5 \\
\hline Agriculture & 4.7 \\
\hline Industry & \\
\hline Services & 8.9 \\
\hline
\end{tabular}

Source: Asian Development Bank, Key Indicators Indonesia 2007

Table 3: International Trade Position for Indonesia 2007

\begin{tabular}{|l|c|l|c|}
\hline Exports total US\$ ml & 126458 & Imports total US\$ ml & 114192 \\
\hline Japan & 23476 & Singapore & 32412 \\
\hline United States & 13826 & China, People's Republic & 13966 \\
\hline Singapore & 13325 & Japan & 9794 \\
\hline China, People's Republic & 11077 & United States & 4658 \\
\hline South Korea & 8335 & South Korea & 6380 \\
\hline Malaysia & 5468 & Thailand & 5245 \\
\hline India & 4120 & Malaysia & 5658 \\
\hline Australia & 3969 & Australia & 3687 \\
\hline Thailand & 3659 & Saudi Arabia & 3478 \\
\hline Germany & 3226 & Germany & 2395 \\
\hline
\end{tabular}

Source: Asian Development Bank, Key Indicators for Asia and the Pacific: Indonesia 2008

\section{CONCLUSION}

In the Indonesian context, the country has made much progress in developing its non-oil sector, but now more than ever, it needs very much to develop a more cohesive export oriented economy; and SME promotion lies at the very core of this effort. The Indonesian economy has remained somewhat stable in spite of the many challenges it has faced in the years since the Asian Financial Crisis and subsequent reformation of the political system and democratization that have come to pass. Table 4 summarizes the positive direction the Indonesian economy is likely to take:

Table 4: Indonesia Economic Forecast 2008-2013

\begin{tabular}{|l|c|c|c|c|c|c|}
\hline \multicolumn{1}{|c|}{ Key Indicators } & $\mathbf{2 0 0 8}$ & $\mathbf{2 0 0 9}$ & $\mathbf{2 0 1 0}$ & $\mathbf{2 0 1 1}$ & $\mathbf{2 0 1 2}$ & $\mathbf{2 0 1 3}$ \\
\hline Real GDP growth (\%) & 6.1 & 3.7 & 3.8 & 4.6 & 5.2 & 5.5 \\
\hline Consumer price inflation (av;\%) & 10.4 & 7.0 & 6.6 & 5.6 & 5.5 & 5.4 \\
\hline Budget balance (\% of GDP) & -1.4 & -1.6 & -1.5 & -1.3 & -0.9 & -0.8 \\
\hline Current account balance (\% of GDP) & 0.5 & 0.6 & 0.7 & 0.7 & 0.6 & 0.6 \\
\hline Deposit rate (av;\%) & 8.1 & 8.8 & 8.2 & 7.3 & 7.2 & 7.0 \\
\hline Exchange rate Rp : US\$ (av) & 9,349 & 9,633 & 9,727 & 9,788 & 9,806 & 9,823 \\
\hline Exchange rate Rp : Yen (av) & 8,823 & 9,352 & 9,900 & 10,330 & 10,458 & 10,486 \\
\hline
\end{tabular}

Source: The Economist Intelligence Unit, 2008 
Based on the past work done by the authors on entrepreneurship development, it is recommended that Indonesia can learn from two neighbors who have had to deal with similar challenges. Venkataramany and Fox (2009), in their study of SME development in India, note that "the priority must be to unite the diverse units of the SMEs under an organized structure and integrate their operations into that of major global firms." Indonesia should do likewise as it is somewhat a mirror image of India in both its state of development and its national priorities. As Indonesian culture has been traditionally averse to entrepreneurial activity, it can learn from the experience from Singapore which has faced the same condition. Bhasin (2007) studied the policy Singapore implemented to foster entrepreneurship that can apply well to Indonesia. Policy measures promoting risk-taking include changing the mindset through education, creating an environment that accepts failure, allowing for free expression, which induces innovation and very strong financial incentives, and tax breaks that increase entrepreneurial risk-taking.

\section{AUTHOR INFORMATION}

Dr. Venkataramany serves as an Associate Professor of Management in the Dauch College of Business \& Economics at Ashland University, Ashland, Ohio where he teaches global management and global finance. Besides teaching commitments abroad, he also serves as an examiner for doctoral theses. He received his MBA, MS and $\mathrm{Ph} . D$. from the University of Miami, Coral Gables, Florida, US. His research interests are risk management in global banks, emerging financial markets and FDI in developing economies.

Balbir B. Bhasin serves as an Associate Professor of International Business at the John F. Welch College of Business, Sacred Heart University, Fairfield, Connecticut and Luxembourg. He holds a Master of International Management degree from Thunderbird School of Global Management, Glendale, Arizona and a Ph.D. in International Business from the University of South Australia, Adelaide, Australia. He was the president of a private investment bank in New York, and CEO of an international business information company in the Far East. His research interests are in cross-cultural studies and FDI in Asian markets. He advises companies on opportunities in Emerging Asia.

\section{REFERENCES}

1. APEC, "Indonesia Experience on Entrepreneurship Development: On the Perspective of Regulation" SME WG Meeting, Agenda Item 6.1 Vancouver, 9-10 March 2004

2. APEC, "Policies and Strategies of SME Development: Indonesian Submission" $26^{\text {th }}$ SME WG Meeting, Agenda Item 14.4 Kaohsiung, Chinese Taipei 30 March to 4 April, 2008

3. APEC, "The Need to Develop SME Global market Network: Indonesian Submission" $26^{\text {th }}$ SME WG Meeting, Agenda Item 18.6 Kaohsiung, Chinese Taipei 30 March to 4 April, 2008

4. Asian Development Bank, Key Indicators for Asia and the Pacific: Indonesia 2008 http://www.adb.org/Documents/Books/Key_Indicators/2008/

5. Bhasin, Balbir "Fostering Entrepreneurship: Developing a Risk-taking Culture in Singapore" New England Journal of Entrepreneurship, Vol. 10 No. 2, Fall 2007

6. CIA, “The World Factobook" Indonesia 2009 https://www.cia.gov/library/publications/the-worldfactbook/geos/id.html

7. Cole, Stroma "Entrepreneurship and empowerment: Considering the barriers - a case study from Indonesia" Tourism Review, Vol. 55 No. 4, pp 461-473, 2007

8. Economist "Country Briefing” Indonesia: Factsheet 2009 http://www.economist.com/Countries/Indonesia/profile.cfm?folder=Profile-FactSheet

9. Harvie, C. "East Asian SME Capacity Building, Competitiveness and Market Opportunities in a Global Economy" Department of Economics, University of Wollongong, Working Paper 04-16, 2004

10. Hayashi, Mitsuhiro "Development of SMEs in the Indonesian Economy" Economics Working Paper No. 2003-01, Australian National University, Canberra 2004

11. Indarti, Nurul, and Marja Langenberg, "Factors Affecting Business Success among SMEs: Empirical Evidences from Indonesia", presented at The second bi-annual European Summer University 2004, University of Twente, Enschede, The Netherlands, September, 19-21st, 2004

12. Ministry of Cooperatives and Small and Medium Enterprises (MSME), Government of the Republic of Indonesia website at: http://www.depkop.go.id/ accessed 11 April, 2009 
13. Prihatin Dwi Riyanti, B. "Factors influencing the success of small-scale entrepreneurs in Indonesia" In B. N. Setiadi, A. Supratiknya, W. J. Lonner, \& Y. H. Poortinga (Eds.) Ongoing themes in psychology and culture, International Association for Cross-Cultural Psychology. Melbourne, Florida, 2004

14. Sandee, Henry and Ibrahim, Buddy "Evaluation of SME Trade and Export Promotion in Indonesia" Asian Development Bank Technical Assistance: SME Development, Jakarta, April 2002

15. Susanto, Joseph "'Creative Entrepreneurship in Indonesia: Problems, Strategies and Challenges - a case study" Study Meeting on Creative Entrepreneurship, The Employers' Association of Indonesia, Asian Productivity Organization, 2005

16. Tambunan, Tulus "Development of SMEs in a Developing Country: The Indonesian Story" Journal of Business and Entrepreneurship, October 2007

17. Tambunan, Tulus "SME development, economic growth and government intervention in a developing country: The Indonesian story" Journal of International Enterprise, Vol. 6 pages 147-167, 22 August 2008

18. Thee Kian Wie "Policies for Private Sector Development in Indonesia" Asian Development Bank Discussion Paper No. 46, March 2006

19. Timberg, Thomas A. "The Political Economy of SME Development Policy in Indonesia - the Policy Process, the Facts, and Future Possibilities" Partnership for Economic Growth (PEG) Project, USAID, Bogor, Indonesia, November 2006

20. UNCTAD: Global Program "Indonesia: Tackling the Challenges for SMEs from Global Integration and Regional Autonomy" meeting on Indonesia held in Jakarta 8-9 June 2004, http://www.globalprogramme.com/_meetings/meetings/080604/080604report.id.pdf

21. Venkataramany, Sivakumar and Fox, Daniel, "Globalization of Entrepreneurship: Overwhelming Institutional Response in Favor of SMEs in India", International Business and Economics Research Journal, Volume 8, Number 3, March 2009, pp. 131-139

22. Wattanapruttipaisan, Thitapha "Promoting SME Development: Some Issues and Suggestions for Policy Consideration" ASEAN Secretariat, October 2002

23. Weaver, Mark K. and Wallace Amy "Strategic Alliances and SME Public Policy Developments in Indonesia” World Development Report 2000-2001, World Bank, Oxford University Press, NY 2000 
NOTES 